\title{
PENGEMBANGAN PERANGKAT PEMBELAJARAN SAINS MODEL STUDENT TEAM ACHIEVEMENT DIVISION (STAD) BERBANTUAN CD INTERAKTIF PADA TOPIK MATTER AND ITS STATE KELAS VII SISWA RSBI
}

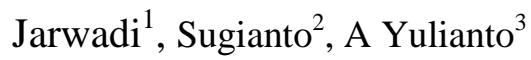 \\ ${ }^{1}$ SMP Negeri 1 Ungaran \\ Email: jar_iin@yahoo.co.id \\ 2,3 Jurusan Fisika \\ Program Studi IPA Pascasarjana \\ Universitas Negeri Semarang
}

\begin{abstract}
Abstrak
Penelitian ini bertujuan mengembangkan perangkat pembelajaran sains dengan model kooperatif tipe Student Team Achievement Division (STAD) berbantuan CD interaktif pada materi Matter and Its State kelas VII yang valid dan efektif. Valid jika memenuhi validitas isi yang ditentukan oleh para ahli. Efektif jika memenuhi tiga indikator keefektifan : (1) lebih dari 50\% siswa memberi respon minat positif terhadap perangkat pembelajaran, (2) $75 \%$ siswa tuntas belajar secara klasikal (3) keaktifan siswa selama proses pembelajaran menunjukkan peningkatan skor. Populasi uji coba dalam penelitian ini adalah siswa kelas VII SMP Negeri 1 Ungaran. Jenis penelitian yang digunakan adalah penelitian pengembangan dengan modifikasi model 4-D dengan tahap define, design, dan develop, (desseminate ditiadakan). Perangkat pembelajaran yang dikembangkan meliputi lesson plan, worksheet, $C D$ interaktif dan tes prestasi belajar. Hasil penelitian menunjukkan bahwa rancangan perangkat pembelajaran seperti disebutkan di atas sudah dilakukan revisi secara bertahap sesuai penilaian dari para ahli dan teman sejawat, hasilnya adalah penilaian lesson plan berkriteria sangat baik (rata-rata 89,3 dari skor teringgi 100), penilaian worksheet berkriteria sangat baik (rata-rata 3,57 dari skor maksimum 4,00), dan penilaian $C D$ interaktif berkriteria sangat baik (rata-rata 3,81 dari skor maksimum 4,00). Jadi perangkat tersebut valid untuk diimplementasikan. Hasil uji coba lapangan menunjukkan ketuntasan pembelajaran mencapai 91,7\%, keaktifan mengalami peningkatan mencapai rata-rata 3,57 dalam kategori cukup aktif, dan 91,66\% siswa menunjukkan respon minat positif terhadap pembelajaran. Hal tersebut menunjukkan perangkat pembelajaran mencapai valid dan efektif.
\end{abstract}

Kata kunci : perangkat pembelajaran, $S T A D, C D$ Interaktif

\section{PENDAHULUAN}

Pembelajaran metode ekspositori meski memiliki keunggulan, namun juga ada celah kelemahan yaitu kurang adanya timbal balik guru dan siswa atau antar siswa itu sendiri. Untuk itu perlu dicoba pendekatan dan metode pembelajaran yang lain. Bruce (2009) dalam penelitiannya menyatakan bahwa pembelajaran kooperatif memiliki peran penting dalam suatu lingkungan belajar yang baru, karena dapat menggabungkan kelompok-kelompok siswa yang yang heterogen. Strategi pembelajaran kooperatif memasuki jalur utama praktik pendidikan karena dapat meningkatkan pencapaian prestasi akademik siswa dan dapat mengembangkan hubungan antar kelompok serta tumbuhnya kesadaran siswa bahwa siswa perlu belajar untuk berpikir dalam menyelesaikan masalah bersama, Miller (2003). 
Dalam suatu penelitian yang lain oleh Adesoji (2009) menyatakan bahwa adanya pengaruh positif bagi siswa penggunaan strategi model pembelajaran kooperatif Student Team Achievement Division $(S T A D)$ terhadap hasil pembelajaran Kimia Kinetik di samping kemampuan matematika yang dimiliki siswa. Model pembelajaran ini memberi kesempatan untuk bekerja sendiri serta bekerjasama dengan orang lain, dan adanya optimalisasi partisipasi siswa. Selain STAD, ada model pembelajaran kooperatif lain yang dapat secara efektif dapat digunakan dalam proses pembelajaran, seperti model Jigsaw II dapat meningkatkan motivasi dan kinerja siswa, serta mengembangkan ketrampilan sosial untuk kerja kelompok dalam membahas hal baru (Kamwing, 2004).

Abad 21 ditandai oleh pesatnya perkembangan ilmu pengetahuan dan teknologi dalam berbagai bidang kehidupan, terutama teknologi informasi dan komunikasi (ICT). Dalam dunia pendidikan pemanfaatan ICT terus meningkat. Youssef\&Dahmani. (2008), dalam penelitiannya mengungkapkan bahwa dalam lingkungan pendidikan ICT menjadi faktor penentu dalam meraih hasil belajar. Salah satu karakter ICT adalah pemanfaatan secara optimal penggunaan media komputer sebagai suatu penunjang pembelajaran. Dalam suatu pembelajaran yang menggunakan media komputer, terkadang jumlah komputer yang digunakan dalam pembelajaran jumlahnya tidak memenuhi jumlah siswa, hal ini bukanlah menjadi penghalang, pembelajaran kooperatif menggunakan komputer dan belajar secara individual dengan komputer tidak menunjukkan perbedaan yang signifikan dalam meraih nilai prestasi (Seymour, 1994).

Electronic Media (E-Media) yang dikemas dalam CD-ROM Interaktif dapat memberikan peningkatan yang signifikan terhadap prestasi belajar siswa dan dapat memberikan keluwesan bagi siswa dalam mengeksplorasi kemampuannya secara mandiri (Adri, 2008). Komputer multimedia yang dikemas dalam $C D$ Interaktif mempunyai beberapa keunggulan dibandingkan bentuk video atau gambar dua dimensi lainnya. Menurut Sovocom Company, sebagaimana dikutip oleh Sutikno (2009:105), tingkat kemampuan daya ingat manusia dengan menggunakan media audio sekitar 10\%, dengan media verbal sekitar $20 \%$ dan dengan memanfaatkan media audio visual mencapai $50 \%$.

Penelitian Herlanti et al.(2007) menyebutkan keunggulan multimedia komputer dalam imagery tools membuat siswa mampu lebih lama menyimpan abstraksi konsep dalam struktur kognitifnya, meskipun berkonstribusi negatif terhadap pemahaman siswa sebagai akibat dari berkurangnya waktu peran pengajar karena tergantikan oleh komputer multimedia.

STAD (Student Team Achievement Division) adalah salah satu model pembelajaran kooperatif, di dalamnya terdapat lima komponen utama meliputi presentasi kelas, siswa dalam kelompok, adanya kuis, skor perkembangan individu dan pengakuan terhadap kelompok . 
Penerapan strategi pembelajaran berbantuan $C D$ Interaktif dengan model kooperatif STAD menjadikan pembelajaran lebih bervariasi, keaktifan dan minat belajar siswa dapat ditumbuhkembangkan dan pada akhirnya prestasi belajar siswa akan meningkat.

Salah satu masalah yang dihadapi oleh SMP Negeri 1 Ungaran adalah rendahnya prestasi belajar siswa pada pembelajaran sains (IPA), khususnya prestasi belajar pada Evaluasi Hasil Belajar (EHB). EHB adalah tes yang diselenggarakan oleh Direktorat Pembinaan SMP untuk seluruh RSBI di Indonesia. Data yang diperoleh peneliti, bahwa hasil nilai prestasi belajar EHB mata pelajaran IPA pada tahun ajaran 2008/2009, kelas VII memperoleh nilai rata-rata 55,16 dan kelas VIII memperoleh nilai rata-rata 56,69. Sedangkan pada tahun ajaran 2009/2010, pencapaian hasil rata-rata nilai prestasi belajar EHB kelas VII adalah 63,54, kelas VIII memperoleh nilai rata-rata 67,00 dan kelas IX memperoleh nilai rata-rata 65,68. Dari hasil EHB yang diperoleh tersebut, belum sesuai dengan harapan yang diinginkan, karena masih di bawah Kriteria Ketuntasan Minimal (KKM), dimana KKM yang telah disepakati bersama oleh Musyawarah Guru Mata Pelajaran (MGMP) tingkat sekolah sebesar 70 .

Topik Matter and Its State (Zat dan Wujudnya) merupakan salah satu materi pembelajaran yang sulit, hal ini ditunjukkan dari hasil analisis Ujian Nasional (UN) 2009/2010 yang diperoleh oleh siswasiswi SMP Negeri 1 Ungaran. Dalam Ujian Nasional tersebut, topik Matter and Its State terurai menjadi dua sub topik, yaitu Density dan Thermal Expansion. Persentase penguasaan materi soal IPA siswa SMP Negeri 1 Ungaran pada sub topik Density adalah 50,44 sedangkan pada subtopik Thermal Expansion adalah 46,02 dan 69,64.

Berdasarkan perolehan nilai Evaluasi Hasil Belajar (EHB), hasil analisis Ujian Nasional (UN) 2009/2010 dan kondisi SMP Negeri 1 Ungaran, maka perlu diadakan penelitian intensif untuk meningkatkan hasil belajar siswa. Salah satu faktor utama untuk meningkatkan hasil belajar adalah mengembangkan perangkat pembelajaran. Maka dalam penelitian ini mengambil judul "Pengembangan Perangkat Pembelajaran Sains Model Student Team Achievement Division (STAD) Berbantuan CD Interaktif pada Topik Matter and Its State kelas VII siswa RSBI".

Dari uraian latar belakang tersebut, dapat dirumuskan suatu permasalahan sebagai berikut: (1) Bagaimanakah proses dan hasil pengembangan perangkat pembelajaran sains model kooperatif tipe STAD berbantuan $C D$ Interaktif pada siswa RSBI pada topik Matter and Its State yang valid? (2) Apakah pembelajaran dengan menggunakan perangkat pembelajaran sainsmodel kooperatif tipe STAD berbantuan CD Interaktif pada siswa RSBI pada topik Matter and Its State efektif? 
STAD merupakan model pembelajaran kooperatif secara garis besar model ini terdiri terdiri dari 4 langkah (Slavin, 2005: 143), yaitu : pembentukan kelompok heterogen, penjelasan materi dan kegiatan kelompok, pelaksanaan kuis atau evaluasi, dan pemberian penghargaan.

$C D$ Interaktif dapat digunakan pada pembelajaran di sekolah sebab cukup efektif meningkatkan hasil belajar siswa terutama komputer (Depdiknas, 2008:30). Kelebihan lain dari $C D$ Interaktif ini adalah siswa dapat belajar secara mandiri, tidak harus tergantung kepada guru/instruktur. Siswa dapat memulai belajar kapan saja dan dapat mengakhiri sesuai dengan keinginannya.

Keaktifan siswa yang adalah keaktifan yang dipenuhi dengan cerminan dari kreatifitas siswa. Indikator aktivitas dan indikator kreatifitas terpadu sehingga memunculkan instrumen keaktifan siswa yang akan diukur. Minat adalah sesuatu yang mengidentifikasi keberadaan pribadi seseorang (Nugraheni, 2010).

\section{METODE PENELITIAN}

Penelitian ini dikategorikan ke dalam penelitian pengembangan. Pengembangan yang dimaksud adalah pengembangan perangkat pembelajaran sains yang sesuai dengan prinsip-prinsip pembelajaran kooperatif tipe STAD. Perangkat pembelajaran yang dikembangkan meliputi: (1) Lesson Plan, (2) Worksheet, (3) CD Interaktif, dan (4) Tes Prestasi Belajar (TPB). Penelitian ini dilaksanakan selama tiga bulan dari pertengahan bulan akhir bulan April sampai dengan bulan Juni 2011. Obyek penelitian adalah siswa SMP Negeri 1 Ungaran yang berada di Jl. Diponegoro No. 197 Ungaran, Kabupaten Semarang.

Pengembangan perangkat pembelajaran menggunakan model pengembangan yang dikemukakan oleh Thiagarajan, Sammel dan Sammel (Trianto, 2007:65) yang dikenal dengan sebutan Four-D Model (Model 4-D), yaitu define (pendefinisian/ penetapan), design (perancangan), develop (pengembangan), dan disseminate (penyebaran). Oleh karena fokus penelitian ini adalah untuk menghasilkan perangkat pembelajaran, maka penelitian ini berakhir sampai tahap develop. Dengan demikian terjadi modifikasi dari model 4-D menjadi 3-D.

Instrumen yang digunakan untuk mengembangkan perangkat pembelajaran adalah lembar validasi Lesson Plan, Worksheet, CD Interaktif dan Tes Prestasi Belajar. Data ini berupa pernyataan para ahli tentang aspek-aspek perangkat pembelajaran.

Metode angket digunakan untuk mengumpulkan data tentang respon siswa terhadap pelaksanaan pembelajaran. Metode Tes digunakan untuk mengumpulkan data tentang keefektifan perangkat pembelajaran. Indikator untuk keefektifan perangkat pembelajaran adalah: (1) Tuntas belajar secara klasikal, suatu kelas dikatakan tuntas belajar apabila kelas tersebut telah mencapai $75 \%$ siswa telah 
mencapai batas ketuntasan minimal $\mathrm{p} \geq 0,7$ dengan $\mathrm{p}$ adalah proporsi jawaban benar, (2) Keaktifan siswa yang diamati oleh guru mitra selama proses pembelajaran menunjukkan peningkatan skor, (3) Lebih dari 50\% siswa memberi respon minat terhadap perangkat pembelajaran.

\section{HASIL DAN PEMBAHASAN}

\section{Hasil Penelitian}

Salah satu topik yang sulit dipahami siswa kelas VII adalah materi Zat dan Wujudnya (Matter and Its State). Secara rinci topik Matter and Its State terdiri dari: The State of Matter, Density, and Thermal Expansion,

Penilaian perangkat pembelajaran meliputi 5 aspek yaitu (1) perumusan tujuan pembelajaran, (2) pemilihan dan pengorganisasian materi pembelajaran, (3) pemilihan sumber belajar/media pembelajaran, (4) metode pembelajaran, (5) penilaian hasil belajar .

Tabel 1 Hasil Tugas Kelompok (Task)

\begin{tabular}{cccccccc}
\hline \multirow{2}{*}{ No } & \multirow{2}{*}{ Group } & \multicolumn{7}{c}{ Nilai } & \multirow{2}{*}{ Rata2 } \\
\cline { 3 - 6 } & & Task1 & Task2 & Task3 & Task4 & Task5 & \\
\hline \multirow{2}{*}{1} & Newton & 82,5 & 92,5 & 95 & 95 & 85 & $\mathbf{9 0}$ \\
2 & Pascal & 63,7 & 77,5 & 87,5 & 85 & 76,2 & $\mathbf{7 7 , 9}$ \\
3 & Einstein & 75 & 80 & 78,7 & 81,2 & 68,7 & $\mathbf{7 6 , 7}$ \\
4 & Boyle & 80 & 80 & 73,7 & 78,7 & 71,2 & $\mathbf{7 6 , 7}$ \\
5 & Galileo & 56,2 & 76,2 & 77,5 & 72,5 & 62,5 & $\mathbf{6 8 , 9}$ \\
6 & Volta & 67,5 & 68,7 & 75 & 77,5 & 72,5 & $\mathbf{7 2 , 2}$ \\
& Rata-rata & $\mathbf{7 0 , 8}$ & $\mathbf{7 9 , 1}$ & $\mathbf{8 1 , 2}$ & $\mathbf{8 1 , 6}$ & $\mathbf{7 2 , 7}$ & \\
\hline
\end{tabular}

Tabel 2 Hasil Tes Prestasi Belajar

\begin{tabular}{cccccc}
\hline No & Hasil Tes & Rata-rata & Tertinggi & Terendah & Ketuntasan (\%) \\
\hline 1 & Uji coba 1 & 70,4 & 100 & 60 & $\mathbf{4 5 , 8}$ \\
2 & Uji coba 2 & 76,7 & 100 & 60 & $\mathbf{6 2 , 5}$ \\
3 & Uji coba 3 & 78,3 & 100 & 60 & $\mathbf{8 7 , 5}$ \\
4 & Uji coba 4 & 82,5 & 100 & 60 & $\mathbf{9 5 , 8}$ \\
5 & Uji coba 5 & 70,8 & 100 & 60 & $\mathbf{5 8 , 3}$ \\
6 & Seluruh materi & 82,8 & 100 & 68 & 91,7 \\
\hline
\end{tabular}


Tabel 3 Hasil Angket Respon Siswa

\begin{tabular}{ccccc}
\hline No & Respon Siswa & $\begin{array}{c}\text { Rata-rata } \\
(\boldsymbol{\%})\end{array}$ & Tertinggi (\%) & Terendah (\%) \\
\hline 1 & Sangat Setuju (SS) & 37,74 & 50 & 8,3 \\
2 & Setuju (S) & 53,92 & 67 & 38 \\
3 & Ragu (R) & 7,59 & 25 & 0 \\
4 & Tidak Setuju (TS) & 0,49 & 2 & 0 \\
\hline
\end{tabular}

Tabel 4 Hasil Pengamatan Keaktifan

\begin{tabular}{cccccccccccc}
\hline \multirow{2}{*}{ Ujicoba } & \multicolumn{10}{c}{ Aspek Penilaian Keaktifan } & \multirow{2}{*}{ Rerata } \\
\cline { 2 - 10 } & $\mathbf{1}$ & $\mathbf{2}$ & $\mathbf{3}$ & $\mathbf{4}$ & $\mathbf{5}$ & $\mathbf{6}$ & $\mathbf{7}$ & $\mathbf{8}$ & $\mathbf{9}$ & $\mathbf{1 0}$ & \\
\hline Ujicoba 1 & 3,79 & 3,67 & 3,58 & 3,67 & 3,58 & 2,42 & 2,83 & 4,58 & 2,63 & 2,25 & $\mathbf{3 , 3}$ \\
Ujicoba 2 & 3,71 & 3,67 & 3,75 & 3,83 & 3,88 & 2,58 & 2,88 & 4,71 & 2,38 & 2,58 & $\mathbf{3 , 4}$ \\
Ujicoba 3 & 3,83 & 3,88 & 4 & 4,13 & 4 & 2,71 & 3 & 4,79 & 2,54 & 2,92 & $\mathbf{3 , 5 8}$ \\
Ujicoba 4 & 4 & 4,08 & 4,38 & 4,13 & 4,17 & 3,17 & 3,29 & 4,79 & 2,83 & 3,42 & $\mathbf{3 , 8 3}$ \\
Ujicoba 5 & 4,04 & 3,96 & 4,42 & 4,17 & 4,04 & 3,25 & 3,58 & 4,38 & 2,96 & 3,5 & $\mathbf{3 , 8 3}$ \\
Jumlah & $\mathbf{3 , 8 8}$ & $\mathbf{3 , 8 5}$ & $\mathbf{4 , 0 3}$ & $\mathbf{3 , 9 8}$ & $\mathbf{3 , 9 3}$ & $\mathbf{2 , 8 3}$ & $\mathbf{3 , 1 2}$ & $\mathbf{4 , 6 5}$ & $\mathbf{2 , 6 7}$ & $\mathbf{2 , 9 3}$ & $\mathbf{3 , 5 9}$ \\
\hline
\end{tabular}

\section{Pembahasan}

Penilaian validator dan revisi terhadap lesson plan meliputi revisi bagian yang terkait langsung dengan syllabus, revisi tata tulis, alokasi waktu, dan revisi substansi lesson plan. Hasil penilaian lesson plan dalam kategori sangat baik dengan skor rata-rata 89,3. Penilaian validator terhadap worksheet menunjukkan aspek format, aspek bahasa dan aspek isi dalam kategori sangat baik dengan skor ratarata total 3,57 (dari skor maksimum 4,00). Worksheet yang dikerjakan secara kelompok, dan $C D$ Interaktif sebagai medianya telah menunjukkan keaktifan siswa dalam berpendapat dan berdiskusi di dalam kelompoknya.

Hasil Tes ada dua macam, yaitu Tes yang berupa tugas dikerjakan secara kelompok (Task) dan Tes yang dikerjakan secara individual berupa Tes Prestasi Belajar (TPB).

Hasil kerja kelompok pada pertemuan ke 1 sampai dengan pertemuan ke 4, terjadi peningkatan nilai Task rata-rata yang cukup signifikan dari 70,8 pada uji coba 1 menjadi 79,1 pada uji coba 2 kemudian 81,2 pada uji coba ke 3 dan 81,6 pada uji coba ke 4. Namun terjadi penurunan pada uji coba ke 5 yaitu menjadi 72,7 .

Uji coba Tes Prestasi Belajar dilakukan sebanyak 6 kali, 5 kali uji coba yang pertama menggunakan tes soal pilihan ganda dengan jumlah 5 butir soal pilihan ganda dengan durasi 10 menit 
dan satu kali tes dengan materi menyeluruh dengan jumlah 25 butir soal pilihan ganda dengan alokasi waktu 60 menit.

Hasil Tes Prestasi Belajar pada uji coba ke 1 sampai dengan ke 4 menunjukkan adanya peningkatan. Pada uji coba ke 1 dengan nilai rata-rata 70,4 dengan ketuntasan belajar 45,8\%, uji coba ke 2 dengan nilai rata-rata 76,7 dengan ketuntasan belajar 62,5\%, uji coba ke 3 dengan nilai rata-rata 78,3 dengan ketuntasan belajar 87,5\%, uji coba ke 4 dengan nilai rata-rata 82,5 dengan ketuntasan belajar 95,8\%. Namun pada uji coba ke 5 nilai rata-rata mengalami penurunan menjadi 70,8 dengan ketuntasan belajar 58,3\%. Tes Prestasi Belajar dengan materi menyeluruh yaitu materi dari uji coba ke 1 sampai dengan materi uji coba ke 5 diperoleh nilai rata-rata 82,8 dengan ketuntasan belajar 91,7\%.

Dari perbandingan rerata nilai Task, Tes Pretasi Belajar dan Ketuntasan Belajar ada peningkatan yang signifikan pada rentang waktu antara uji coba pertama hingga uji coba ke 4. Hasil perbandingan tersebut menunjukkan bahwa uji coba ke 4 merupakan rerata nilai puncak, setelah itu pada uji coba ke terjadi penurunan nilai rerata. Dari data tersebut menunjukkan bahwa pembelajaran sains model Student Team Achievement Division (STAD) berbantuan CD Interaktif akan efektif digunakan sampai dengan 4 pertemuan atau 4 kali uji coba, jika digunakan lebih dari itu siswa menunjukkan gejala kejenuhan yang berdampak penurunan pada nilai rerata Task, TPB maupun Ketuntasan Belajar. Dalam kegiatan belajar, motivasi sebagai daya penggerak di dalam diri siswa yang menimbulkan, menjamin kelangsungan dan memberikan arah kegiatan belajar, sehingga tujuan dapat tercapai (Sardiman, 2006:102). Motivasi siswa dapat ditumbuhkan diantaranya dengan cara menerapkan model pembelajaran dan media pembelajaran yang lebih bervariasi.

Hasil kerja kelompok pada pertemuan ke 1 sampai dengan pertemuan ke 4, terjadi peningkatan nilai Task rata-rata yang cukup signifikan dari 70,8 pada uji coba 1 menjadi 79,1 pada uji coba 2 kemudian 81,2 pada uji coba ke 3 dan 81,6 pada uji coba ke 4. Namun terjadi penurunan pada uji coba ke 5 yaitu menjadi 72,7 .

Hasil Tes Prestasi Belajar pada uji coba ke 1 sampai dengan ke 4 menunjukkan adanya peningkatan. Pada uji coba ke 1 dengan nilai rata-rata 70,4 dengan ketuntasan belajar 45,8\%, uji coba ke 2 dengan nilai rata-rata 76,7 dengan ketuntasan belajar 62,5\%, uji coba ke 3 dengan nilai rata-rata 78,3 dengan ketuntasan belajar 87,5\%, uji coba ke 4 dengan nilai rata-rata 82,5 dengan ketuntasan belajar 95,8\%. Namun pada uji coba ke 5 nilai rata-rata mengalami penurunan menjadi 70,8 dengan ketuntasan belajar 58,3\%. Tes Prestasi Belajar dengan materi menyeluruh yaitu materi dari uji coba ke 1 sampai dengan materi uji coba ke 5 diperoleh nilai rata-rata 82,8 dengan ketuntasan belajar 91,7\%.

Penurunan Tes Prestasi Belajar siswa pada uji coba kelima, dimungkinkan karena kejenuhan siswa dalam mengikuti proses belajar mengajar, mengingat selama empat kali pertemuan sebelumnya 
dan pertemuan yang kelima (uji coba terakhir), guru menggunakan model pembelajaran dan media yang sama. Hal ini menyebabkan motivasi belajar siswa menurun, selanjutnya berdampak pada rendahnya tingkat pemahaman siswa terhadap topik pembelajaran yang diajarkan guru. Dalam kegiatan belajar, motivasi sebagai daya penggerak di dalam diri siswa yang menimbulkan, menjamin kelangsungan dan memberikan arah kegiatan belajar, sehingga tujuan dapat tercapai (Sardiman, 2006:102). Motivasi siswa dapat ditumbuhkan diantaranya dengan cara menerapkan model pembelajaran dan media pembelajaran yang lebih bervariasi.

Keaktifan siswa secara umum mengalami peningkatan dari uji coba pertama sampai uji coba ke 5. Uji coba pertama dengan skor rata-rata 3,3 uji coba kedua dengan rata-rata skor 3,4 uji coba ketiga dengan skor rata-rata sebesar 3,6 dan uji coba keempat dan kelima dengan skor rata-rata sama yaitu 3,8, sehingga skor rata-rata total dari lima kali uji coba adalah 3,54 dengan kategori cukup aktif.

Hasil respon minat siswa menunjukkan bahwa yang memberikan tanggapan Sangat Setuju $37,74 \%$ dan Setuju 53,92\%. Respon positif siswa terhadap perangkat pembelajaran adalah 91,66\%, dengan kata lain pembelajaran kooperatif model STAD dapat meningkatkan minat, motivasi dan kinerja siswa, selain pembelajaran kooperatif model Jigsaw II (Kamwing, 2004)

\section{KESIMPULAN}

Analisis hasil validasi pengembangan Perangkat Pembelajaran menyatakan bahwa perangkat yang dikembangkan tersebut valid.

Analisis terhadap hasil uji coba memenuhi indikator keefektifan dimana ketuntasan belajar secara klasikal mencapai $91,7 \%$ atau lebih dari $75 \%$, keaktifan siswa menunjukkan adanya peningkatan dengan rata-rata keaktifan sebesar 3,88 atau dalam kategori cukup aktif, dan respon minat siswa terhadap perangkat pembelajaran mencapai $91,66 \%$. 


\section{DAFTAR PUSTAKA}

Adesoji, F. A. and T. L. Ibraheem. 2009. Effects of Student Teams Achievement Divisions Strategy and Mathemathics Knowledge on Learning Outcomes in Chemical Kinetics. The Journal of International Social Research, 6(2): 15-23.

Adri, M. \& N. Azhar. 2008. Pengembangan Paket Multimedia Interaktif Sebagai Sarana Belajar Mandiri Mahasiswa. Makalah dipresentasikan pada Seminar Nasional Konstribusi Pendidikan Jarak Jauh (PJJ) dalam Pencapaian Milenium Development Goals (MDGs), Universitas Terbuka Tangerang Banten, 10 Maret.

Arikunto, S. 1998. Prosedur Penelitian Suatu Pendekatan Praktek. Edisi Revisi VI. Jakarta: PT. Rineka Cipta.

Bruce, C. A. 2009. Cooperative Learning: New Promise for Today's Diverse Classrooms. National Association of Elementary Principals, 1: 1-2.

Depdiknas. 2008. Media Pembelajaran dan Sumber Belajar. Jakarta: Departemen Pendidikan Nasional

Duncan, T. \& H. Kennett. 2011. Physics (14 ${ }^{\text {th }}$ ed). London: Cambridge University Press.

Herlanti, Y., N.Y. Rustaman, \& W. Setiawan. 2007. Konstribusi Wacana Multimedia Terhadap Pemahaman dan Retensi Siswa. Jurnal Pendidikan IPA Metamorfosa, 2(1): 29-38.

Kamwing, C. 2004. Using Jigsaw II in Teacher Education Programmes. Hongkong Teacher Centre Journal, 3: 91-97.

Miller, C.K. and R.L. Peterson. Cooperative Learning. 2003. The Safe and Responsive Schools Project, 2: 1-2.

Nugraheni, D. 2010. Pengembangan Perangkat Pembelajaran IPA Terpadu Berbasis Inquiry Melalui Lesson Study. Tesis. Semarang: FMIPA Universitas Negeri Semarang.

Sardiman, A.M. 2006. Interaksi dan Motivasi Belajar Mengajar. Jakarta: Raja GrafindoPersada.

Seymour, S. R. 1994. Operative Computer Learning with Cooperative Task and Reward Structures. Journal Technology Education, 5(2): 19-30.

Slavin, R.E. 2005. Cooperative Learning Teori, Riset dan Praktik (terjemahan). Bandung: Nusa Media.

Sutikno, S. 2009. Belajar dan Pembelajaran Upaya Kreatif dalam Mewujudkan Pembelajaran yang Berhasil. Bandung: Prospect.

Trianto. 2007. Model Pembelajaran Terpadu dalam Teori dan Praktek. Jakarta: Prestasi Pustaka.

Youssef, A.B. \& M. Dahmani. 2008. The Impact of ICT on Student Performance in Higher Education: Direct Effects, Indirect Effects and Organisational Change. Revista de Universidad y Sociedad del Conocimiento (RUSC), 5: 45-55. 